\title{
EFFECT OF ULINASTATIN ON REGULATORY T CELLS AND T HELPER 17 CELLS IN PATIENTS WITH SEVERE SEPSIS
}

\author{
GUOHUI LI ${ }^{1}$, JILIN MA ${ }^{2}$, LONG CAI ${ }^{3}$, ZHANLI SHI ${ }^{4}$, JING SUN ${ }^{4}$, JIAYING ZHANG $^{4}$, ZHIHUI \\ $\mathrm{LI}^{4}$, LEIMIN SUN ${ }^{4}$, HONGJUAN ZHOU ${ }^{3}, \mathrm{KUN} \mathrm{FANG}^{4}$, $\mathrm{SU} \mathrm{YU}^{2 *}$ \\ ${ }^{I}$ Department of Occupational Medicine, Hang Zhou Red Cross Hospital, Hangzhou, 310003, China \\ ${ }^{2}$ Department of Rheumatology, Immunology and Nephrology, Hang Zhou Red Cross Hospital, Hangzhou, 310003, China \\ ${ }^{3}$ Central Laboratory, Hang Zhou Red Cross Hospital, Hangzhou, 310003, China \\ ${ }^{4}$ Department of Intensive Care Unit, Hang Zhou Red Cross Hospital, Hangzhou, 310003, China
}

*corresponding author:dryusu_ys@163.com

Manuscript received: December 2018

\begin{abstract}
The aim of this study was to assess the effect of ulinastatin (UTI) on the levels of immune regulatory cells, pro-inflammatory mediators, and the expression of severe sepsis in regulatory $\mathrm{T}$ cells (Treg) and $\mathrm{T}$ helper 17 (Th17) cells monocytes. Peripheral blood was obtained from severe sepsis patients. The blood was divided in two groups, the experimental group treated with ulinastatin and the control group without any treatment. The rate of CD4+ CD25+ Foxp3+ Treg cells in CD4+ T cells was analysed by flow cytometry. CD4+ CD25+ Foxp3+ Treg cells were purified by magnetic cell labelling (MACS) and expanded in vitro by culture with addition of CD3/CD8 Dynal beads and IL 2 . The cells number, activity and purity after expanding the cells for 0 day, 7 days, 14 days and 21 days were determined. The rate of CD4+ CD25+ Foxp $3+$ and CD $8+$ CD25+ Foxp3+ cells in the control cell group was $(6.41 \pm 0.37) \%$ and $(6.67 \pm 0.48) \%$. The rate of CD4+ CD25+ Foxp3+ and CD8 + CD25+ Foxp3+ cells gradually decreased with the increase of UTI concentration. When the concentration of UTI reached $1600 \mathrm{U} / \mathrm{mL}$, the percentage of CD4+ CD25+ Foxp3+ and CD $8+\mathrm{CD} 25+$ Foxp3 + cells were $(3.40 \pm 0.16) \%$ and $(3.53 \pm$ $0.22) \%$ respectively. UTI inhibited the differentiation of CD4+ CD25- cells into CD4+ IL-17 cells and CD4+ CD25+ Foxp3+ cells and the differentiation of CD8+ CD25- cells into CD8+ IL-17 cells and CD8+ CD25+ Foxp3+ cells. The inhibitory effects observed were dose dependent.
\end{abstract}

\section{Rezumat}

Scopul acestui studiu a fost evaluarea efectului ulinastatinului (UTI) asupra celulelor implicate în reglarea imună, a mediatorilor pro-inflamatorii, precum și expresia sepsisului sever la nivelul celulelor T de reglatoare (Treg) și T helper 17 (Th17). A fost recoltat sânge periferic de la pacienți cu sepsis sever. Numărul celulelor CD4+ CD25+ Foxp3+ Treg din populaţia de limfocite T CD4+ a fost analizată prin citometrie în flux. Numărul celulelor, activitatea şi puritatea acestora au fost determinate la momentul inițial, după 7 zile, 14 zile și respectiv 21 de zile. Procentul celulelor CD4+ CD25+ Foxp3+ și CD8+ CD25+ Foxp3+ în grupul de control a fost $6,41 \pm 0,37 \%$ și, respectiv, 6,67 $\pm 0,48 \%$. Procentul celulelor CD4+ CD25+ Foxp3+ și CD8+ CD25+ Foxp3+ a scăzut proporțional cu creșterea concentrației de UTI. Pentru concentrația de 1600 U/ml, procentul celulelor CD4+ CD25+ Foxp3+ și CD8+CD25+ Foxp3+ a fost de 3,40 $\pm 0,16 \%$ și, respectiv, 3,53 $\pm 0,22 \%$. UTI a inhibat diferențierea celulelor CD4+ CD25- în celule CD4+ IL-17 și celule CD4+ CD25+ Foxp3+ precum şi diferențierea celulelor CD8+ CD25- în celule CD8+ IL-17 și celule CD8+ CD25+ Foxp3+. Efectele inhibitoare au fost dependente de doză.

Keywords: regulatory $\mathrm{T}$ cell, $\mathrm{Foxp}_{3}$, MACS, severe sepsis, ulinastatin

\section{Introduction}

Sepsis is defined as life-threatening organ dysfunction caused by a dysregulated host response to infection and is a leading cause of death worldwide $[1,2]$. Septic shock occurs in response to an infection with resistant bacterial germs [3, 4]. The inflammatory response to microbial invasion is a continuous process that can progressively evolve to worsening, if not treated $[5,6]$. Ulinastatin (UTI), a drug used in acute inflammatory disorders, has been tested in animal models of autoimmune inflammatory diseases, such as ulcerative colitis, acute pancreatitis and crescentic glomerulo-nephritis $[5,7]$.
In a previous study, intravenous administration of ulinastatin reduced mortality in patients with severe sepsis in the modified intention-to-treat analysis [8]. In the current study, we used magnetic cell labelling $\left(\mathrm{MAC}_{\mathrm{S}}\right)$ for the enrolment and sorting the cells from the peripheral blood of patients with severe sepsis. We investigated the role of regulatory $\mathrm{T}$ cells (Treg) and $\mathrm{T}$ helper 17 (Th17) and related cytokines in patients with severe sepsis in order to determine the potential therapeutic effect of ulinastatin, its effect on Treg and Th17 cells, and to investigate the role of ulinastatin in the differentiation and function of Treg and Th17 cells in vitro. 
FARMACIA, 2019, Vol. 67, 2

\section{Materials and Methods}

\section{Patients}

All patients with severe sepsis were from Hang Zhou Red Cross Hospital, China. The experiments were approved by the hospital ethics committee. Written informed consent was obtained at the moment of admission from either the patient or, in the event that the patient lacked capacity, a personal or professional legal representative for participating in the study.

Patients were included in the study within 24 hours after meeting the inclusion criteria for severe sepsis. Exclusion criteria: basic disease prognosis was poor and in the short term may become the leading causes of death (such as stroke, craniocerebral injury, postoperative cardiopulmonary resuscitation (CPR) and late malignant tumour), as well as people with autoimmune diseases such as rheumatoid arthritis, multiple sclerosis and systemic lupus erythematosus (SLE), asthma and other diseases or patients that used within 3 months prior to admission corticosteroids or immunosuppressants.

The data regarding demographic data, sepsis diagnosis, intensive care unit (ICU) procedures, and a datestamped log of all invoiced items, including medications, laboratory orders, diagnostic and therapeutic services were taken from medical records of each patient.

There were no significant differences in the blood pressure, lactic acid levels, urine volume, oxygenation index, serum creatinine levels, serum bilirubin, platelet count and blood coagulation among all the patients with sepsis. APACHE II and SOFA scores were no significant different among the patients.

Patients had received standard care according to the ACCP/SCCM: Surviving Sepsis Campaign 2001 guidelines. Antibiotics were administered to treat identified infections. In the study were included 120 cases of severe sepsis, 30 cases in the control group and 90 cases in the experimental group, with no significant difference regarding the clinical medication among all patients. Peripheral blood was collected from all the patients involved in the experiment. In the experimental group peripheral blood samples were treated with ulinastatin in doses of $0 \mathrm{U} / \mathrm{mL}, 100 \mathrm{U} / \mathrm{mL}, 400 \mathrm{U} / \mathrm{mL}$ and $1600 \mathrm{U} / \mathrm{mL}$. The percentages of peripheral blood, lymphocyte subsets, Treg and Th17 cells were measured by flow cytometry and the ratio of the two was calculated for the values obtained in day 1, 3, 5 and 7 .

Sampling

Before the ulinastatin treatment, human CD3+ CD25$\mathrm{T}$ cells which include CD4+ CD25 $\mathrm{T}$ cells and $\mathrm{CD} 8+\mathrm{CD} 25$ - cells were determined in the peripheral blood of all patients. The purity of the obtained $\mathrm{T}$ cells was determined by the separation and enrichment of the magnetic beads and the enrichment of the cells. From each patient $120 \mathrm{~mL}$ of peripheral blood was collected and mononuclear cells were obtained by density ladder centrifugation.

Cell Sorting and T-cell Suppression

Using magnetic beads to select human CD3 $+\mathrm{T}$ cells (Miltenyi Biotec), the CD3 $+\mathrm{T}$ cells were enriched according to the instructions of the kit. The obtained CD3+ T cells were incubated using anti-CD25APC (allophycocyanin) antibody (eBioscience), and the anti- CD25+ cells were removed using anti-antiAPC magnetic beads, and CD3 + CD25- T cells were obtained and counted.

The purity of CD3 + CD25 - T cells obtained by the magnetic bead separation and enrichment was determined. A quantity of $5 \times 10^{7}$ cells were added to the $80 \mu \mathrm{L}$ PBS (phosphate buffer saline) and the $10 \mu \mathrm{L}$ CD3-PE (phycoerythrin) antibody (eBioscience) and the $10 \mu \mathrm{L} \mathrm{CD} 25-\mathrm{APC}$ antibody (eBioscience). The mixture was incubated for $30 \mathrm{~min}$. After centrifugation, the supernatant was discarded. $1 \mathrm{~mL}$ PBS was added and the sample was centrifuged at $300 \mathrm{x}$ g for $10 \mathrm{~min}$ and then the above liquid was discarded. Finally, the concentration of CD3 + CD25- T cells was detected by flow cytometry using the standard procedure.

Treatment groups and cell culture

Control group: 30 samples of CD3+ CD25 -T cells treated with $0 \mathrm{U} / \mathrm{mL}$ UTI.

Experimental groups: 90 samples of CD3+ CD25$\mathrm{T}$ cells were divided in 3 subgroups treated with $100 \mathrm{U} / \mathrm{mL}, 400 \mathrm{U} / \mathrm{mL}$ and $1600 \mathrm{U} / \mathrm{mL}$ ulinastatin. In each group it was evaluated the effect of the treatment on the differentiation of CD3+ CD25- in Th17 T cells.

On the first day of culture, anti-CD3 $(5 \mu \mathrm{g} / \mathrm{mL})$, anti-CD28 $(5 \mu \mathrm{g} / \mathrm{mL})$, anti-IL-4 $(5 \mu \mathrm{g} / \mathrm{mL})$ and antiIFN- $\gamma-(5 \mu \mathrm{g} / \mathrm{mL})$ as well as the cytokines TGF- $\beta(2$ $\mathrm{ng} / \mathrm{mL})$ and IL-23 (10 ng/mL) were added in each plate. The cells were cultured for $72 \mathrm{~h}$ in $50 \mathrm{ng} / \mathrm{mL}$ PMA (phorbol-12-myristate-13-acetate) with 750 $\mathrm{ng} / \mathrm{mL}$ ionomycin and $10 \mathrm{~g} / \mathrm{mL}$ brefeldin $\mathrm{A}$ as stimulating factors. The cells were then separated through flow cytometry in CD4+ IL-17 + cells and CD8+ IL-17 + cells.

Statistical analysis

All results were analysed using SPSS 13.0 software, and all quantitative data were presented as mean \pm standard deviation (SD). Statistical analysis was performed by use of one-way ANOVA. For other analysis, the SNK-q test was used for multiple comparisons between groups. A value of $\mathrm{p}<0.05$ was considered statistically significant.

\section{Results and Discussion}

Human CD3+ CD25- T cell enrichment.

Before the UTI treatment, for all the participants from which the blood was collected, CD3+ CD25$\mathrm{T}$ cells enrichment and sorting was performed in order to test the purity of the cells and it can be 
FARMACIA, 2019, Vol. 67, 2

seen in Figure 1 and Table I that the CD3+ CD25cells were in a concentration of $89.70 \pm 1.85 \%$ and CD3- CD25- were in a concentration of $10.23 \pm$ $1.87 \%$ (Figure 1 and Table I). The levels of CD4+ CD25- T cells and CD8+ CD25- T cells were measured

1

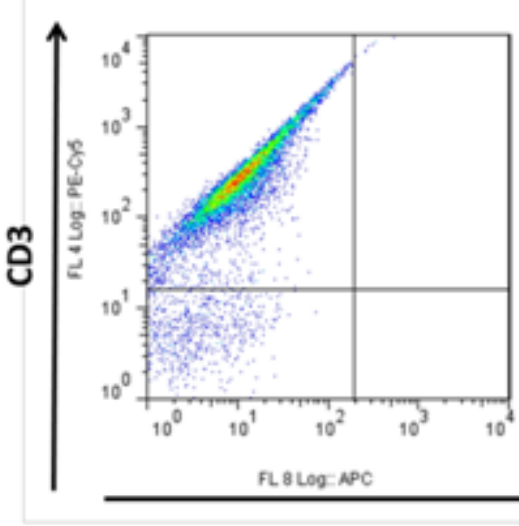

from $\mathrm{CD} 3+\mathrm{CD} 25-\mathrm{T}$ cells obtained. The percentage of CD4+ CD25- cells and CD8+ CD25- cells were $60.24 \pm 0.24 \%$ and, respectively, $34.19+0.44 \%$ (Figures 2, 3 and Table II).
2

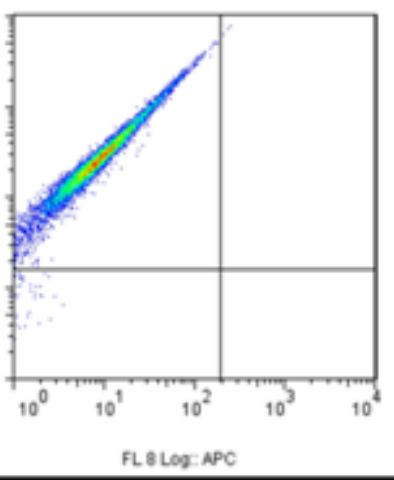

CD25

Figure 1.

Detection of cells concentration by flow cytometry: CD3+ CD25- T cells

Table I

The evaluation of cells concentration by flow cytometry: the percentage of CD3+ CD25- T cells $(\%$, mean \pm SD)

\begin{tabular}{|c|c|c|}
\hline Antibodies & Cell type & Cell levels (\%) \\
\hline \multirow{4}{*}{ CD3-PE-Cy5/CD25-APC } & CD3+ CD25- & $89.70 \pm 1.85$ \\
\cline { 2 - 3 } & CD3+ CD25+ & $0.07 \pm 0.05$ \\
\cline { 2 - 3 } & CD3- CD25- & $10.23 \pm 1.87$ \\
\cline { 2 - 3 } & CD3- CD25+ & $0.00 \pm 0.00$ \\
\hline
\end{tabular}

PE - phycoerythrin; Cy5 - Cyanine 5; APC- allophycocyanin

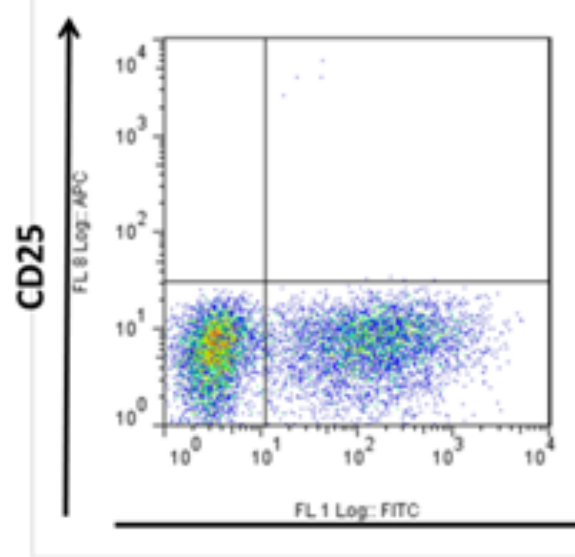

2

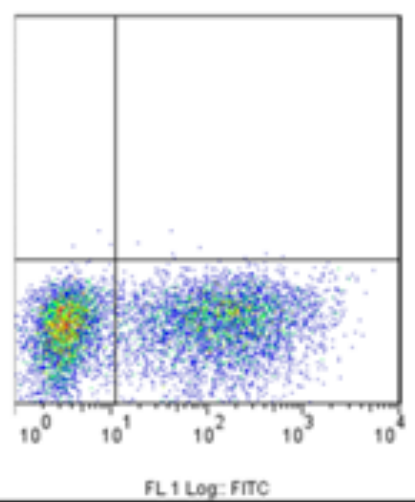

CD4
3

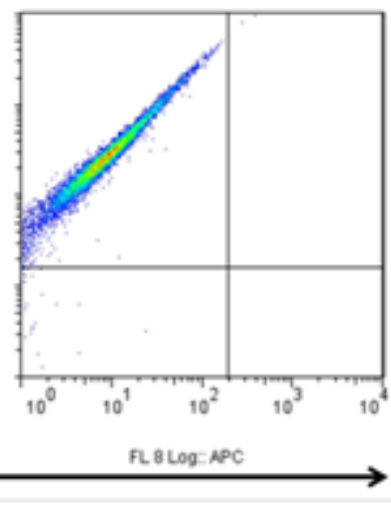

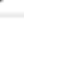



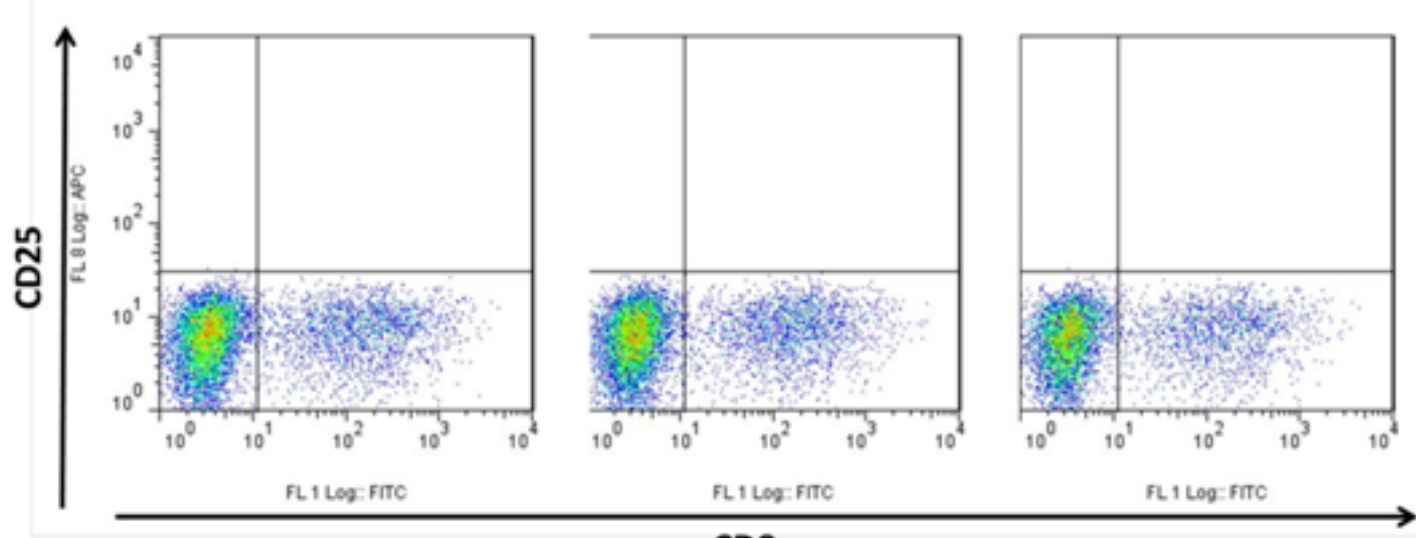

CD8

Figure 3.

Detection of cell concentration by flow cytometry: CD8+ CD25- T cells

Table II

The evaluation of cells concentration by flow cytometry: concentrations of CD4+ CD25- and CD8+ CD25- (\%,

\begin{tabular}{|c|c|c|}
\hline Antibodies & Cell type & Cell levels (\%) \\
\hline \multirow{4}{*}{ CD4-FITC/CD25-APC } & CD4- CD25- & $30.77 \pm 0.29$ \\
\cline { 2 - 3 } & CD4+CD25- & $60.24 \pm 0.24$ \\
\cline { 2 - 3 } & CD4- CD25+ & $0.03 \pm 0.02$ \\
\cline { 2 - 3 } & CD4+ CD25+ & $1.12 \pm 0.07$ \\
\hline \multirow{4}{*}{ CD8-FITC/CD25-APC } & CD8- CD25- & $65.77 \pm 0.43$ \\
\cline { 2 - 3 } & CD8+CD25- & $34.19 \pm 0.44$ \\
\cline { 2 - 3 } & $\mathrm{CD} 8-\mathrm{CD} 25+$ & $0.02 \pm 0.02$ \\
\cline { 2 - 3 } & $\mathrm{CD} 8+\mathrm{CD} 25+$ & $0.02 \pm 0.01$ \\
\hline
\end{tabular}

mean $\pm \mathrm{SD})$

Note: FITC - fluorescein isothiocyanate; APC - allophycocyanin

The effects of ulinastatin on CD3+CD25 - T cells differentiation into Th17 cells.

The results of this study showed that different concentrations of ulinastatin induce differentiation of CD3 + CD25- T cells into CD4+ IL 17 + cells (Figure 4) and CD8+ IL-17 + cells (Figure 5). Ulinastatin inhibited the differentiation of CD4+ CD25- T cells into CD4+ IL17 cells and CD4+ CD25+ Foxp3+ cells. The percentages of CD4+ CD25+ Foxp3+ and
CD8+ CD25+ Foxp3+ cells in the control group were $6.41 \pm 0.37 \%$ and $6.67 \pm 0.48 \%$ respectively. The percentages of CD4+ CD25+ Foxp3+ and CD8+ CD25+ Foxp3+ cells gradually decrease with the increase of UTI concentration. For UTI concentration of $1600 \mathrm{U} / \mathrm{mL}$, the percentage of CD4+ CD25+ Foxp3+ and CD8+ CD25+ Foxp3+ cells was of $3.40 \pm 0.16 \%$ and $3.53 \pm 0.22 \%$, respectively (Figure 6, Table III).

Table III

The effect of ulinastatin on the differentiation of CD4+ CD25-T cells into CD4+ IL17 cells and CD4+ CD25+ Foxp3 + cells $(\%$, mean \pm SD $)$

\begin{tabular}{|c|c|c|}
\hline Antibodies & Goup & Cell concentration (\%) \\
\hline \multirow{4}{*}{ CD4-FITC/IL-17-PE } & Control & $6.41 \pm 0.37$ \\
\cline { 2 - 3 } & $100 \mathrm{U} / \mathrm{mL}$ UTI & $5.13 \pm 0.07$ \\
\cline { 2 - 3 } & $400 \mathrm{U} / \mathrm{mL}$ UTI & $4.96 \pm 0.04$ \\
\cline { 2 - 3 } & $1600 \mathrm{U} / \mathrm{mL}$ UTI & $3.40 \pm 0.16$ \\
\hline \multirow{4}{*}{ CD8-FITC/IL-17-PE } & Control & $6.67 \pm 0.48$ \\
\cline { 2 - 3 } & $100 \mathrm{U} / \mathrm{mL}$ UTI & $4.90 \pm 0.10$ \\
\cline { 2 - 3 } & $400 \mathrm{U} / \mathrm{mL}$ UTI & $4.19 \pm 0.08$ \\
\cline { 2 - 3 } & $1600 \mathrm{U} / \mathrm{mL}$ UTI & $3.53 \pm 0.22$ \\
\hline
\end{tabular}

Note: FITC - fluorescein isothiocyanate; PE - phycoerythrin; UTI - Ulinastatin 
FARMACIA, 2019, Vol. 67, 2

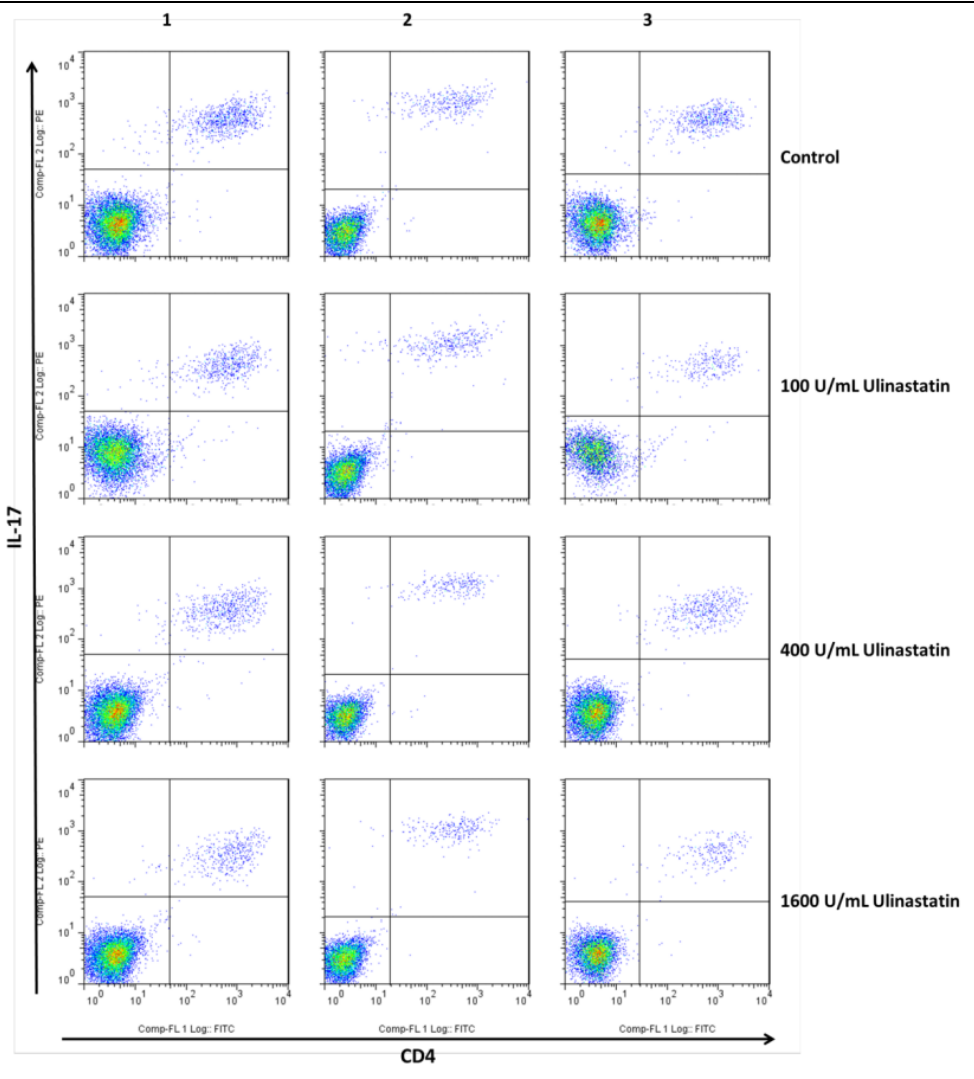

Figure 4.

Detection of CD4+ IL-17+ cells by flow cytometry

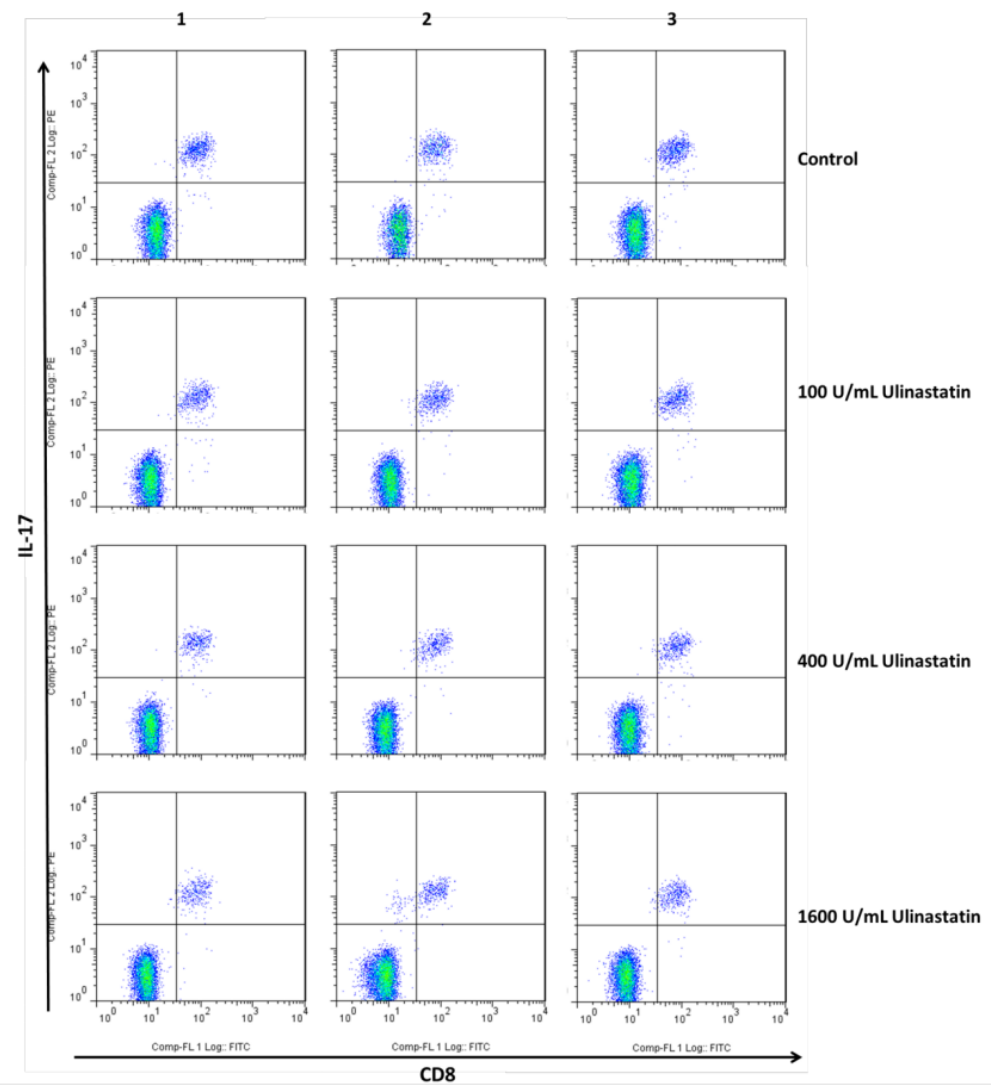

Figure 5.

Detection of CD8+ IL-17+ cells by flow cytometry 

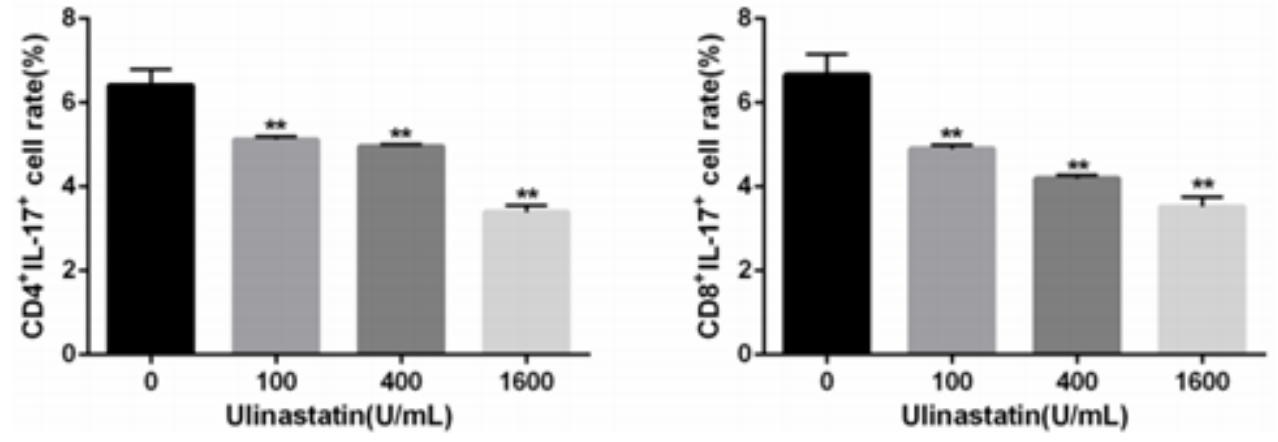

Figure 6.

The evaluation of cells concentration by flow cytometry: the levels of CD4+ IL-17and CD8+ IL-17(** p $<0.01$ vs. $1600 \mathrm{U} / \mathrm{mL}$ Ulinastatin)

Table IV

The effect of ulinastatin on the differentiation of CD4+ CD25-T cells into CD4+ IL17 cells and CD4+ CD25+ Foxp3 + cells $(\%$, mean $\pm \mathrm{SD})$

\begin{tabular}{|c|c|c|}
\hline Antibodies & Goup & Cell concentration (\%) \\
\hline \multirow{4}{*}{ CD4-FITC/IL-17-PE } & Control & $6.41 \pm 0.37$ \\
\cline { 2 - 3 } & $100 \mathrm{U} / \mathrm{mL}$ UTI & $5.13 \pm 0.07$ \\
\cline { 2 - 3 } & $400 \mathrm{U} / \mathrm{mL}$ UTI & $4.96 \pm 0.04$ \\
\cline { 2 - 3 } & $1600 \mathrm{U} / \mathrm{mL}$ UTI & $3.40 \pm 0.16$ \\
\hline \multirow{4}{*}{ CD8-FITC/IL-17-PE } & Control & $6.67 \pm 0.48$ \\
\cline { 2 - 3 } & $100 \mathrm{U} / \mathrm{mL}$ UTI & $4.90 \pm 0.10$ \\
\cline { 2 - 3 } & $400 \mathrm{U} / \mathrm{mL}$ UTI & $4.19 \pm 0.08$ \\
\cline { 2 - 3 } & $1600 \mathrm{U} / \mathrm{mL}$ UTI & $3.53 \pm 0.22$ \\
\hline
\end{tabular}

Note: FITC - fluorescein isothiocyanate; PE - phycoerythrin; UTI - Ulinastatin

Severe sepsis has become one of the most common causes of death in ICU [9]. Cellular immune disorders and acute inflammatory reaction are the two key factors that favour severe sepsis. In the early stage, immune cells and inflammatory response cells can be activated, producing a large number of inflammatory mediators, so that the body produces a strong proinflammatory and anti-inflammatory response, which cannot be well controlled and eventually will lead to immune dysfunction. Traditionally, it was considered that the host immune response to sepsis is characterized by an initial hyper-inflammatory phase that evolves over several days into a more protracted immunosuppressive phase $[10,11]$. Many patients develop severe systemic oedema. Pleural and peritoneal effusion, lower blood pressure, hypoxia, even circulating and respiratory failure. The mechanism of capillary leakage is not completely clear. Most researchers believe that endotoxins and some damaging factors factors can activate the immune system to release pro-inflammatory citokines (TNF $\alpha$, IL-1-, IL-6) that activate the effector cells and release inflammatory mediators such as TXA2 and PGI2. Despite improvements in access to care, imaging and interventional techniques, severe sepsis continues to be associated with significant morbidity and mortality. Wang's study found a role for ulinastatin in limiting the acidosis state and attenuating the coagulation disbalance induced by coecal ligation and puncture
(CLP) [12]. Such results suggested that ulinastatin's protection was also related to its positive influence on coagulatory disorders.

Similar to our study, Huang's study suggests that ulinastatin is useful for bronchial asthma, it can effectively relieve clinical symptoms, raises the seric levels of IL-2 and IL-4 and regulates the immune function by changing the relative percentages of $\mathrm{T}$ cells subsets [13]. In Karnad's trial, the addition of ulinastatin was associated with severe organ dysfunction in adult patients with severe sepsis [14]. Ulinastatin can also decrease the expression of Treg and Thl7, inverse the ratio of Treg/Thl7, and ameliorate the immune status, which can improve the prognosis of patients with severe sepsis [15].

The main limitation of this study is that it was performed in a single institution with a limited number of patients. The total number of study participants could be increased by including multiple units; however, the level of complexity, the required personnel to consistently perform the analyses and the required places limits the widespread of the units participation. Another limitation of this study is the incomplete data at later time points as patients were discharged; collection of blood after hospital discharge would allow for a more robust generalizable analysis. 


\section{Conclusions}

In conclusion, our study showed that Treg and Th17 cells play an important role in the occurrence and development of severe sepsis. Ulinastatin inhibited the differentiation of CD4+ CD25- T cells into CD4+ IL17 cells and CD4+ CD25+ Foxp3+ cells. Ulinastatin ca influence the differentiation of Treg and Th17 cells in vitro. When the concentration of ulinastatin reached $1600 \mathrm{U} / \mathrm{mL}$, the inhibitory effect of ulinastatin was more obvious. Overall this study provided new research ideas and experimental evidences for the treatment of sepsis by intra-intestinal administration of UTI.

\section{Acknowledgement}

This work was supported by Science and Technology Program of Zhejiang Province, Public-interest Technology Research for Social Development Project 2015C33278; Tianpu Research Fund Project UF201307.

\section{Conflict of interest}

The authors declare no conflict of interests.

\section{References}

1. Singer M, Deutschman CS, Seymour CW, ShankarHari M, Annane D, Bauer M, Bellomo R, Bernard GR, Chiche JD, Coopersmith CM, Hotchkiss RS, Levy MM, Marshall JC, Martin GS, Opal SM, van der Poll T, Vincent JL, Angus DC, The Third International Consensus Definitions for Sepsis and Septic Shock (Sepsis-3). JAMA, 2016; 315: 801-810.

2. Liu GB, Cui XQ, Wang ZB, Wen L, Duan HL, Detection of serum procalcitonin and hypersensitive C-reactive protein in patients with pneumonia and sepsis. J Biol Regul Homeost Agents, 2018; 32(5): 1165-1169.

3. Zlatian O, Balasoiu AT, Balasoiu M, Cristea O, Docea AO, Mitrut R, Spandidos DA, Tsatsakis AM, Bancescu G, Calina D, Antimicrobial resistance in bacterial pathogens among hospitalised patients with severe invasive infections. Exp Ther Med., 2018; 16: 4499-4510

4. Ungureanu A, Zlatian O, Mitroi G, Drocaş A, Ţîrcă T, Călina D, Dehelean C, Docea AO, Izotov BN, Rakitskii V, Cioboată R, Spandidos DA, Tsatsakis AM, Găman A, Staphylococcus aureus colonisation in patients from a primary regional hospital. Mol Med Rep., 2017; 16: 8771-8780.
5. Georgescu M, Tăpăloagă PR, Tăpăloagă D, Furnaris F, Ginghină O, Negrei C, Giuglea C, Bălălău C, Ștefănescu E, Popescu IA, Georgescu D, Evaluation of antimicrobial potential of nigella sativa oil in a model food matrix. Farmacia, 2018; 66(6): 1028-1036.

6. Calina D, Docea, AO, Roşu L, Zlatian O, Roşu AF, Anghelina F, Rogoveanu O, Arsene A., Nicolae A C, Drăgoi C M, Tsiaoussis J, Tsatsakis A M, Spandidos DA, Drakoulis N, Gofiță E, Antimicrobial resistance development following surgical site infections. $\mathrm{Mol}$ Med Rep., 2017; 15(2): 681-688.

7. Xing HF, Wen H, Wang DJ, Wang HH, Zhao M, Effect of ulinastatin combined with haemodialysis on severe acute pancreatitis. Farmacia, 2017; 65(5): 714-719.

8. Karnad DR, Bhadade R, Verma PK, Moulick ND, Daga MK, Chafekar ND, Iyer S, Intravenous administration of ulinastatin (human urinary trypsin inhibitor) in severe sepsis: a multicenter randomized controlled study. Intensive Care Med., 2014; 40(6): 830-838

9. Vincent JL, Rello J, Marshall J, Silva E, Anzueto A, Martin CD, Moreno R, Lipman J, Gomersall C, Sakr Y, Reinhart K, EPIC II Group of Investigators, International study of the prevalence and outcomes of infection in intensive care units. JAMA, 2009; 302(21): 2323-2329.

10. Hotchkiss R S, Monneret G, Payen D, Immunosuppression in sepsis: a novel understanding of the disorder and a new therapeutic approach. Lancet Infect Dis., 2013; 13(3): 260-268.

11. Hotchkiss RS, Karl IE, The pathophysiology and treatment of sepsis. $N$ Engl J Med., 2003; 348(2): 138-150.

12. Wang N, Liu X, Zheng X, Cao H, Wei G, Zhu Y, Fan $\mathrm{S}$, Zhou $\mathrm{H}$, Zheng $\mathrm{J}$, Ulinastatin is a novel candidate drug for sepsis and secondary acute lung injury, evidence from an optimized CLP rat model. Int Immunopharmacol., 2013; 17(3): 799-807.

13. Huang W, Effects of ulinastatin on intestinal barrier function and flora translocation in patients with severe sepsis. Clin Res Pract., 2018; 3(01): 16-17.

14. Qin K, Huang D, Zhao BS, Effect of ulinastatin on cardiopulmonary function and immune function in patients with severe sepsis. J Clin Pulm Med., 2017; 22(12): 2190-2193.

15. Karnad DR, Bhadade R, Verma PK, Moulick ND, Daga MK, Chafekar ND, Intravenous administration of ulinastatin (human urinary trypsin inhibitor) in severe sepsis: a multicenter randomized controlled study. Intensive Care Med., 2014; 40(6): 830-838. 